\title{
POTENSI ANTITUMOR EKSTRAK SPONS Crella papilata ASAL TAMAN NASIONAL LAUT KEPULAUAN SERIBU
}

\author{
Nurrahmi Dewi Fajarningsih*), Hedi Indra Januar*), Muhammad Nursid") dan Thamrin Wikanta*)
}

\begin{abstract}
ABSTRAK
Penelitian mengenai potensi antitumor ekstrak spons Crella papilata asal Taman Nasional Laut Kepulauan Seribu (TNKpS) telah dilakukan. Uji toksisitas dilakukan dengan metode BSLT, sedangkan uji sitotoksisitas terhadap sel tumor HeLa dan mieloma dilakukan dengan metode uji MTT. Hasil BSLT yang diperoleh menunjukkan bahwa toksisitas ekstrak kasar metanol Crella papilata $\left(\mathrm{LC}_{50}: 19,99 \mathrm{ppm}\right)$ dan fraksi metanol Crella papilata $\left(\mathrm{LC}_{50}: 21,15 \mathrm{ppm}\right)$ tergolong sangat toksik. Ekstrak Crella papilata memiliki aktivitas sitotoksik yang tinggi terhadap sel tumor HeLa dan mieloma. Respon bioaktivitas ekstrak Crella papilata terhadap sel tumor HeLa lebih tinggi dibandingkan terhadap sel mieloma. Nilai LC $_{50}$ ekstrak kasar metanol Crella papilata terhadap sel HeLa sebesar 12,06 ppm dan terhadap sel mieloma sebesar 18,91 ppm, sedangkan nilai $\mathrm{LC}_{50}$ fraksi metanol Crella papilata terhadap sel HeLa sebesar 7,63 ppm dan terhadap sel mieloma sebesar 17,30 ppm. Metabolit sekunder pada fraksi metanol spons Crella papilata asal Taman Nasional Laut Kepulauan Seribu mempunyai prospek yang menjanjikan untuk diteliti lebih lanjut bioaktivitasnya sebagai antitumor.
\end{abstract}

\section{ABSTRACT: $\quad$ Antitumor potency of sponge Crella papilata from Seribu Islands Marine Na- tional Park. By: Nurrahmi Dewi Fajarningsih, Hedi Indra Januar, Muhammad Nursid and Thamrin Wikanta}

Research on antitumor potency of sponge Crella papilata from Seribu Islands Marine National Park (SIMNP) had been carried out. Toxicity assay was conducted using BSLT method, while cytotoxicity assay against HeLa and mieloma cell lines was conducted using MTT method. The BSLT results showed that toxicity of Crella papilata methanolic crude extract $\left(L C_{50}: 19.99\right.$ $\mathrm{ppm})$ and Crella papilata methanolic fraction $\left(L C_{50}: 21.15 \mathrm{ppm}\right)$ were considered very toxic. The Crella papilata extract had high cytotoxicity activity against HeLa and mieloma tumor cell lines. Bioactivity response of Crella papilata extract against HeLa cell lines was higher than against mieloma cell lines. $L C_{50}$ value of Crella papilata methanolic crude extract against HeLa and mieloma cell lines were 12.06 ppm and 18.91 ppm respectively, while $L C_{50}$ value of Crella papilata methanolic fraction against HeLa and mieloma cell lines were 7.63 ppm and 17.30 ppm respectively. The secondary metabolites of the methanolic fraction needs further investigation.

KEYWORDS: $\quad$ sponge, Crella papilata, antitumor, BSLT, MTT assay, HeLa cell line, mieloma cell lines.

\section{PENDAHULUAN}

Indonesia sebagai negara kepulauan terbesar di dunia, yang terletak di kawasan tropis, merupakan salah satu negara dengan keanekaragaman hayati laut tertinggi (megabiodiversity) di dunia. Karena keanekaragaman hayati yang sangat tinggi tersebut, maka terjadilah kompetisi antar spesies untuk bertahan hidup. Kondisi seperti itu membuat berbagai jenis biota laut, salah satunya spons, mensintesis metabolit sekunder (senyawa bioaktif) yang bersifat toksik sebagai alat pertahanan diri melawan bakteri, fungi, virus (Gudbjarnason, 1999; Sumaryono, 2004), predator maupun persaingan antar mereka sendiri untuk mempertahankan wilayah pertumbuhannya (Russel Kerr, 2003 dalam Widjhati et al., 2004).

Spons merupakan hewan multiseluler sederhana dan memiliki bentuk yang bervariasi. Bentuknya dipengaruhi oleh lingkungan kimia dan lingkungan fisik, seperti kedalaman, arus, ombak dan sedimentasi (Rachmat et al., 2001). Tekanan lingkungan, seperti kompetisi ruang, cahaya, dan sumber lainnya menyebabkan terjadinya keanekaragaman kimia pada berbagai organisme bentik, termasuk spons (Sennet et al., 2002). Keberadaan metabolit bioaktif pada

Peneliti pada Balai Besar Riset Pengolahan Produk dan Bioteknologi Kelautan dan Perikanan 
organisme sessil ini juga merefleksikan adaptasi ekologi yang terbentuk selama evolusi sebagai alat pertahanan diri (Proksch et al., 2003).

Spons asal perairan tropis Indonesia memiliki potensi yang sangat signifikan sebagai sumber senyawa bioaktif untuk dapat dikembangkan lebih jauh menjadi komoditi bernilai ekonomis tinggi (Widjhati et al., 2004). Hasil penelitian Wikanta et al. (2005a) menunjukkan bahwa dari 38 sampel spons dan karang lunak asal Kepulauan Seribu yang ditapis pada tahun 2005 , terdapat beberapa sampel yang menunjukkan potensi bioaktivitas yang menjanjikan. Salah satu spons tersebut adalah spons Crella papilata yang dapat tumbuh dan mampu berkompetisi dengan baik di habitat alaminya di Taman Nasional Laut Kepulauan Seribu. Kawasan yang asli (habitat alami) menjanjikan pertumbuhan spons yang baik, kompetisi antar biota akan tinggi dan masing-masing biota akan memproduksi senyawa bioaktif sebagai respon adaptif. Dalam Chemical Dictionaries of Natural Products 2001 (Anon., 2001), terdapat 9 senyawa yang berasal dari Crella sp. Senyawa-senyawa tersebut adalah : benzylthiocrellidone, crellastatin I, crellastatin A, crellastatin J, crellastatin $K$, crellastatin $L$, crellastatin $M$, dibenzyl disulfide dan phenylmethanethiol. Akan tetapi, tidak terdapat informasi mengenai potensi bioaktivitas dari senyawasenyawa tersebut.

Spons yang kaya akan kandungan metabolit bioaktif dengan aktivitas sitotoksik, antitumor dan antimikrobianya menarik minat para peneliti bioteknologi dan farmasetikal (Pabel et al., 2003). Lebih dari 15.000 produk bahan alam yang ada saat ini dikembangkan dari mikroba, alga dan invertebrata laut. Saat ini, lebih dari 28 produk bahan alam laut berada dalam fase uji klinis dan lebih banyak lagi sedang berada pada fase uji preklinis. Sebagai contoh, discodermolide yang merupakan senyawa antikanker dari spons Discodermia dissolut. Saat ini discodermolide yang memiliki aktivitas melebihi $\mathrm{Taxol}^{\circledR}$, telah lulus uji klinis tahap I (Maxwell et al., 2005).

Saat ini, kanker masih menjadi penyakit penyebab kematian yang tinggi di dunia. Terapi kanker yang ada saat ini masih belum efektif. Banyak obat kanker dengan indikasi therapeutic yang rendah (dosis maksimum dengan efektivitas yang minimum). Tidak semua pasien dan atau jenis kanker responsif terhadap obat-obat kanker (chemotherapic agents). Selain itu, banyak obat-obat kanker yang menimbulkan efek samping dan juga efek resisten (Williams \& Andersen, 2006). Oleh karena itu, pencarian senyawa obat antitumor baru, dengan struktur kimia dan mekanisme reaksi yang berbeda, sangat diperlukan. Hal tersebut yang mendasari dilaksanakannya riset ini. Riset ini bertujuan untuk mengetahui potensi senyawa bioaktif antitumor ekstrak spons Crella papilata asal Taman Nasional Laut Kepulauan Seribu.

\section{BAHAN DAN METODE}

\section{Pengambilan Sampel dan Identifikasi Spons Crella papilata}

Pengambilan sampel spons Crella papilata dilakukan di perairan Taman Nasional Laut Kepulauan Seribu pada tanggal 22 Juni 2005. Sampel seberat 200 gram diambil dengan tangan dari stasiun pengambilan di sekitar Pulau Pramuka menggunakan scuba diving. Sampel tersebut kemudian langsung dimaserasi dengan menggunakan $500 \mathrm{~mL}$ metanol dalam toples plastik tahan pelarut organik, kemudian dibawa ke laboratorium kimia Balai Besar Riset Pengolahan Produk dan Bioteknologi Kelautan dan Perikanan untuk diekstraksi lebih lanjut.

Sebagai dokumentasi, diambil foto spons di habitatnya dan foto spons di permukaan air. Identifikasi sampel dilakukan oleh Pusat Penelitian Oseanografi LIPI.

\section{Ekstraksi Spons Crella papilata}

Ekstraksi spons Crella papilata dilakukan menurut Wikanta et al. (2005b). Setelah sampel dimaserasi dengan $500 \mathrm{~mL}$ metanol teknis $95 \%$ selama 72 jam, maserat disaring dan kemudian dimaserasi kembali dengan pelarut yang sama sebanyak dua kali masingmasing selama 24 jam. Total maserat yang diperoleh (1500 mL) kemudian dievaporasi pada suhu $25^{\circ} \mathrm{C}$ dan tekanan 40 mbar menggunakan Buchi Rotavapor. Setelah pelarut metanol menguap semua, ekstrak dikeringbekukan (freeze drying) hingga diperoleh ekstrak berbentuk serbuk kering (ekstrak kasar metanol). Setelah dilakukan bioasai, selanjutnya ekstrak kasar metanol tersebut difraksinasi dengan menggunakan pelarut etil asetat dan metanol p.a. sebanyak $3 \times 50 \mathrm{~mL}$. Setelah disaring, fraksi etil asetat dan fraksi metanol tersebut dievaporasi menggunakan nitrogen evaporator dan dikeringkan lebih lanjut pada suhu dan tekanan rendah $\left(-40^{\circ} \mathrm{C}\right.$, $300 \times 10^{-3} \mathrm{mbar}$ ) dengan menggunakan freeze dryer.

\section{Uji Toksisitas dengan Brine Shrimp Lethality Test (BSLT)}

Uji toksisitas menggunakan larva udang artemia (BSLT) dilakukan menurut metode Meyer et al.(1982). BSLT merupakan uji toksisitas yang dapat dilakukan dengan cepat, murah dan mudah, sehingga banyak digunakan sebagai tahapan awal (prescreening) dalam penapisan senyawa bioaktif antitumor. 
Pada uji ini digunakan larva udang Artemia salina sebagai hewan uji. Telur Artemia salina (merk ARTEMIA) ditetaskan dalam air laut buatan (38 gram garam dapur dalam $1000 \mathrm{~mL}$ air suling) di bawah lampu TL 15 watt. Setelah 48 jam, telur menetas menjadi nauplii instar III/IV dan siap digunakan sebagai hewan uji. Sebagai larutan stok, ekstrak kasar metanol dan fraksi metanol spons masing-masing dilarutkan dalam dimetil sulfoksida (DMSO). Selanjutnya, dibuat seri konsentrasi ekstrak sebesar 6,$25 ; 12,5 ; 25 ; 50$; dan 100 ppm dari larutan stok tersebut. Pengenceran dilakukan dengan menggunakan larutan garam fisiologis. Konsentrasi akhir DMSO dalam larutan perlakuan tersebut tidak boleh melebihi $5 \%$. Sebagai kontrol, digunakan larutan garam dan DMSO tanpa ekstrak spons. Maksimal kematian larva Artemia salina pada kontrol tidak boleh melebihi $10 \%$ dari total populasi uji. Sepuluh ekor larva Artemia salina dimasukkan ke dalam vial yang berisi ekstrak sampel dalam berbagai seri konsentrasi. Masing-masing perlakuan dan kontrol dilakukan tiga kali ulangan. Selanjutnya, semua vial diinkubasikan di bawah lampu TL 15 watt selama 24 jam. Setelah diinkubasi, jumlah larva Artemia salina yang mati pada tiap vial dihitung untuk menentukan persentase kematiannya. Nilai Lethal Concentration $50\left(\mathrm{LC}_{50}\right)$ dihitung dengan menggunakan analisis probit dengan program MINITAB versi 13.2 dengan selang kepercayaan $95 \%$. Nilai probit persentase kematian Artemia salina versus log konsentrasi diplotkan pada sumbu $\mathrm{x}$ dan $\mathrm{y}$ untuk mendapatkan nilai $\mathrm{LC}_{50}$.

\section{Uji Sitotoksisitas terhadap Sel Kanker HeLa dan Mieloma}

Uji sitotoksisitas dilakukan dengan metode MTT (3-[4,5-dimetilthiazol-2yl]-2,5-difenil tetrazolium bromida) menurut Hughes \& Mehmet (2003). Sel tumor HeLa yang digunakan pada penelitian ini berasal dari US NAMRU (United States Naval Medical Research Unit) Jakarta, sedangkan sel mieloma berasal dari koleksi Fakultas Kedokteran UGM, Yogyakarta. Sel HeLa dan mieloma dikultur dalam media RPMI (Roswell Park Memorial Institue) 1640 lengkap yang mengandung Fetal Bovine Serum (FBS) 10\%, fungizone $0,5 \%$ dan Penisilin-Streptomisin $2 \%$.

Dibuat seri konsentrasi ekstrak Crella papilata sebesar 6,$25 ; 12,5 ; 25 ; 50$; dan 100 ppm dengan menggunakan pelarut RPMI tanpa serum sebanyak 3 ulangan. Dibuat pula 3 macam kontrol, yaitu: kontrol sel (100 $\mu \mathrm{L}$ sel $+100 \mu \mathrm{L}$ media), kontrol media (200 $\mu \mathrm{L}$ media) dan kontrol sampel ( $100 \mu \mathrm{L}$ ekstrak spons $+100 \mu \mathrm{L}$ media). Sebanyak $100 \mu \mathrm{L}$ larutan ekstrak spons dari setiap konsentrasi dimasukkan ke dalam sumuran mikroplat yang telah berisi sel tumor sebanyak $2 \times 10^{4}$ sel $(100 \mu \mathrm{L})$. Kemudian mikroplat diinkubasikan selama 24 jam dalam inkubator $\mathrm{CO}_{2}$. Setelah diinkubasikan selama 24 jam, selanjutnya ke dalam mikroplat ditambahkan $10 \mu \mathrm{L}$ MTT ke dalam tiap sumuran dan diinkubasikan kembali selama 4 jam dalam inkubator $\mathrm{CO}_{2}$. Reaksi MTT dihentikan dengan penambahan sodium dodesil sulfat (SDS) $10 \%$, selanjutnya mikroplat kembali diinkubasikan selama 12 jam dalam ruang gelap pada suhu kamar. Setelah inkubasi tersebut, absorbansi tiap sumuran diukur dengan DYNEX spektrofotometer microplate reader pada panjang gelombang $570 \mathrm{~nm}$.

Penentuan persentase kematian sel dihitung berdasarkan rumus:

$$
\% \text { Mortalitas }=\frac{(A-D)(B-C)}{(A-D)} \times 100 \%
$$

Keterangan: $\quad A=$ Absorbansi kontrol sel

$B=$ Absorbansi sampel

$\mathrm{C}=$ Absorbansi kontrol sampel

$\mathrm{D}=$ Absorbansi kontrol media

Perhitungan nilai LC $_{50}$ dilakukan dengan menggunakan analisis probit dengan program MINITAB versi 13.2 dengan selang kepercayaan $95 \%$. Nilai probit persentase kematian sel HeLa dan Mieloma versus log konsentrasi diplotkan pada sumbu $x$ dan y untuk mendapatkan nilai $\mathrm{LC}_{50}$.

\section{HASIL DAN BAHASAN}

\section{Identifikasi Sampel}

Identifikasi sampel "red" spons Crella papilata dari Taman Nasional Laut Kepulauan Seribu dilakukan oleh Pusat Penelitian Oseanologi LIPI. Hasil identifikasi adalah sebagai berikut :

$$
\begin{array}{ll}
\text { Filum } & \text { : Porifera } \\
\text { Kelas } & \text { :Demospongia } \\
\text { Ordo } & \text { :Poecilosclerida } \\
\text { Famili } & \text { :Crellidae } \\
\text { Genus } & \text { :Crella } \\
\text { Spesies } & \text { :Crella papilata }
\end{array}
$$

Gambar spons di habitatnya (bawah air) dan setelah diambil dari habitatnya disajikan pada Gambar 1.

\section{Brine Shrimp Lethality Test (BSLT)}

Menurut Mc Laughlin \& Thompson (1998) dalam Widiastuti (2004), nilai LC ${ }_{50}$ untuk sitotoksik umumnya adalah sepersepuluh nilai $L_{50}$ yang diperoleh dari BSLT. Carballo et al. (2002) meneliti kelayakan 


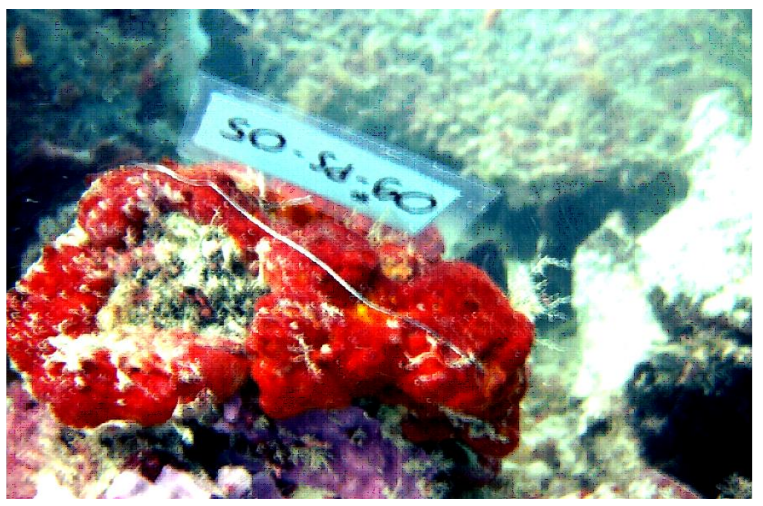

(a)

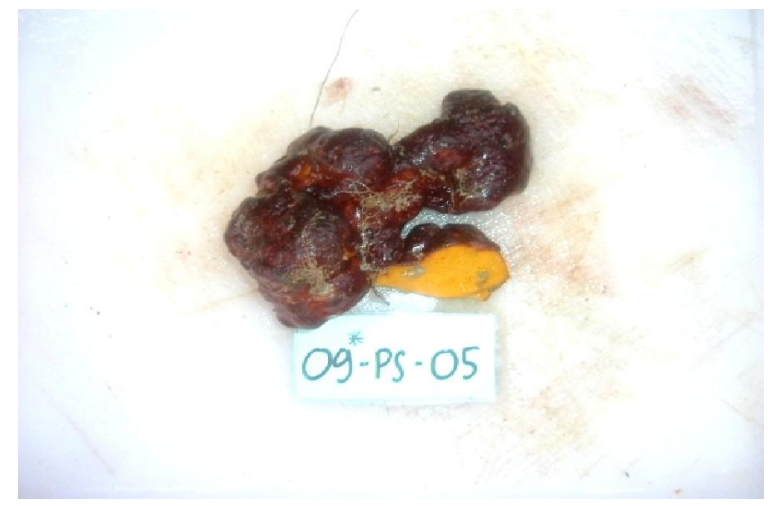

(b)

Gambar 1. Spons Crella papilata di habitatnya (a) dan setelah pengambilan contoh (b). Figure 1. Crella papilata sponge at its habitat (a) and after sampling (b).

penggunaan metode BSLT untuk pengujian aktivitas farmakologi produk bahan alam. Hasil penelitian tersebut menunjukkan adanya korelasi positif antara BSLT dan uji sitotoksik (50\% spesies yang aktif dalam BSLT juga aktif dalam uji sitotoksik).

Tingkat toksisitas suatu ekstrak dapat diketahui dengan menghitung persentase kematian naupli artemia sebagai hewan uji dalam BSLT. Menurut Meyer et al. (1982), suatu ekstrak dianggap sangat toksik bila memiliki nilai $\mathrm{LC}_{50}$ di bawah $30 \mathrm{ppm}$, dianggap toksik bila memiliki nilai $L_{50} 30-1000$ ppm dan dianggap tidak toksik bila nilai $\mathrm{LC}_{50}$ di atas 1000 ppm.

Sebagai tahapan penapisan awal, sampel ekstrak kasar metanol dan fraksi metanol Crella papilata diuji dengan konsentrasi 6,25; 12,5; 25; 50; dan 100 ppm. Diperoleh nilai LC $_{50}$ ekstrak kasar metanol sebesar 19,99 ppm, sedangkan nilai LC $_{50}$ fraksi metanol sebesar 21,51 ppm sehingga keduanya masuk dalam kategori sangat toksik. Nilai $L_{50}$ yang kecil tersebut mengindikasikan tingginya aktifitas senyawa bioaktif yang terkandung dalam ekstrak Crella papilata. Uji biologis terhadap fraksi etil asetat tidak dapat dilakukan karena berat fraksi etil asetat yang diperoleh sangat kecil sehingga tidak mencukupi untuk bahan uji.

Herefa (2000) menyatakan bahwa kondisi yang tidak dapat ditolerir oleh Artemia salina adalah keasaman lingkungan, dimana biota ini hanya dapat hidup dengan baik pada kisaran $\mathrm{pH} 7-8,4$. Turunnya nilai $\mathrm{pH}$ di bawah 7 serta adanya senyawa-senyawa turunan nitrogen non protein akan bersifat racun sehingga menyebabkan kematian bagi Artemia salina tersebut. Derajat keasaman $(\mathrm{pH})$ yang terukur pada larutan uji BSLT ternyata bersifat netral cenderung basa $(\mathrm{pH} 7,8)$, sehingga dapat disimpulkan bahwa faktor keasaman bukan menjadi penyebab kematian Artemia salina pada uji ini.

\section{Uji Sitotoksisitas terhadap Sel Tumor HeLa dan Mieloma}

Studi untuk mempelajari proliferasi, viabilitas dan mortalitas sel dalam rangka pencarian senyawa anti tumor membutuhkan keakuratan kuantifikasi jumlah sel hidup dalam kultur. Uji MTT merupakan uji yang sensitif, kuantitatif dan terpercaya. Reaksi MTT merupakan reaksi reduksi seluler yang didasarkan pada pemecahan garam tetrazolium MTT yang berwarna kuning menjadi kristal formazan yang berwarna biru keunguan. Enzim suksinat dehidrogenase pada mitokondria sel hidup mampu memecah MTT menjadi kristal formazan (Hughes \& Mehmet, 2003). Reaksi tersebut melibatkan piridin nukleotida kofaktor NADH dan NADPH yang hanya dikatalis oleh sel hidup, sehingga jumlah formazan yang terbentuk proporsional dengan jumlah sel yang hidup (Anon., 2005). Semakin banyak sel yang hidup, semakin banyak kristal formazan yang terbentuk, semakin tinggi nilai absorbansi yang diperoleh dan mengindikasikan mortalitas yang rendah.

Foto hasil pembentukan kristal biru formazan oleh sel HeLa dan sel mieloma dengan perlakuan penambahan ekstrak kasar metanol 12,5; 25; dan 50 ppm, dapat dilihat pada Gambar 2.

Hasil penghitungan LC $_{50}$ dengan analisis probit ditampilkan pada Tabel 1.

Tampak bahwa bioaktivitas ekstrak fraksi metanol Crella papilata terhadap sel HeLa ( $\left.\mathrm{LC}_{50}: 7,63 \mathrm{ppm}\right)$ dan sel mieloma ( $\mathrm{LC}_{50}: 17,30 \mathrm{ppm}$ ) lebih tinggi dibandingkan bioaktivitas ekstrak kasar metanol terhadap sel HeLa ( LC $_{50}: 12,06$ ppm) dan sel mieloma 


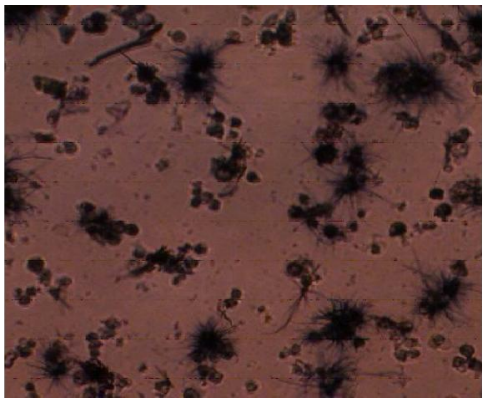

(1)

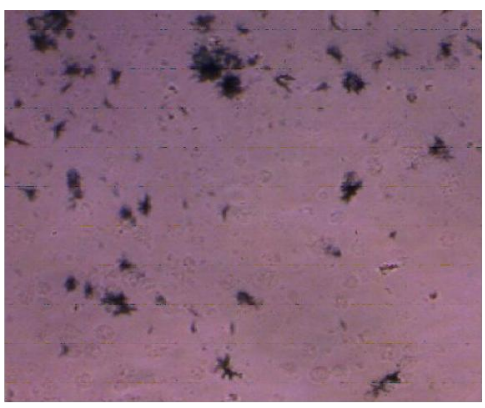

(1)

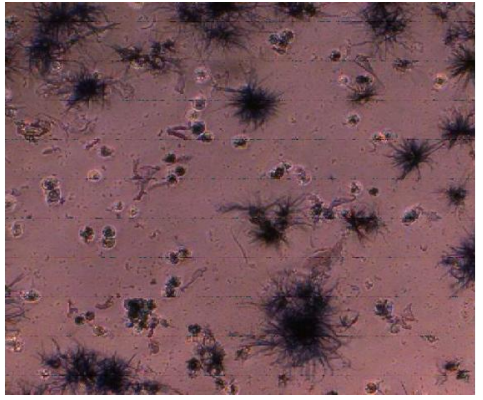

(2)

(A)

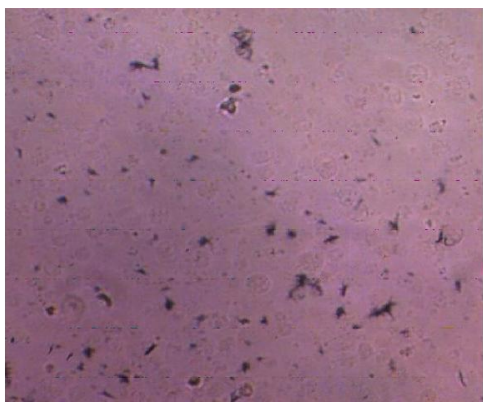

(2)

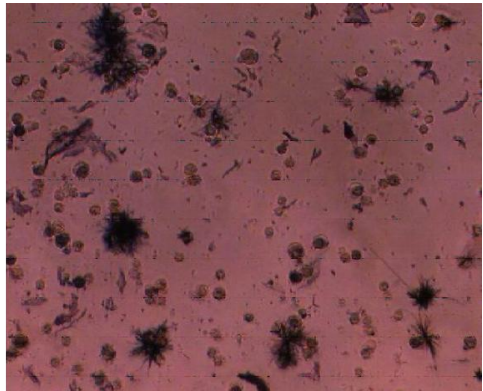

(3)

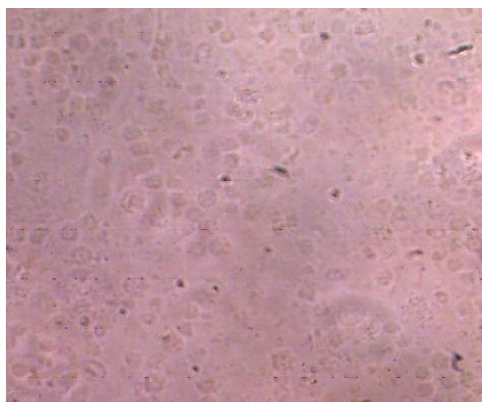

(3)

(B)

Gambar 2. Foto kristal biru formazan pada sel HeLa (A) dan sel mieloma (B) dengan perlakuan penambahan ekstrak kasar metanol Crella papilata 12,5 ppm (1); 25 ppm (2) dan 50 ppm (3).

Figure 2. Picture of blue formazan crystal on HeLa cell lines $(A)$ and mieloma cell lines $(B)$ treated with Crella papilata crude methanolic extract at 12.5 ppm (1); 25 ppm (2) and 50 ppm (3).

Tabel 1. Nilai LC L $_{50}$ ekstrak kasar metanol dan fraksi metanol Crella papilata terhadap sel HeLa dan mieloma. Table 1. $L C_{50}$ value of Crella papilata's methanolic crude extract and methanolic fraction against HeLa and mieloma cell lines.

\begin{tabular}{lcc}
\hline \multicolumn{1}{c}{ Sampel/Samples } & $\begin{array}{c}\text { He La } \\
(\mathbf{p p m})\end{array}$ & $\begin{array}{c}\text { Mieloma } \\
(\mathbf{p p m})\end{array}$ \\
\hline $\begin{array}{l}\text { Ekstrak kasar metanol/ } \\
\text { Methanolic crude extract }\end{array}$ & 12.06 & 18.91 \\
$\begin{array}{l}\text { Fraksi metanol/ } \\
\text { Methanolic fraction }\end{array}$ & 7.63 & 17.3 \\
\hline
\end{tabular}

$\left(\mathrm{LC}_{50}: 18,91 \mathrm{ppm}\right)$. Hal ini sesuai dengan pola umum, yaitu semakin murni suatu komponen, bioaktivitasnya akan semakin meningkat. Dapat kita lihat juga bahwa ekstrak Crella papilata memberikan respon bioaktivitas yang berbeda terhadap sel HeLa dan sel mieloma, dimana bioaktivitas ekstrak Crella papilata terhadap sel HeLa lebih tinggi dibandingkan terhadap sel mieloma.
Menurut Andersen (1991) dalam Sismindari et al. (2002), suatu ekstrak dianggap aktif apabila mampu menyebabkan mortalitas $50 \%$ populasi sel tumor pada konsentrasi di bawah 30 ppm ( LC $\left._{50}<30 \mathrm{ppm}\right)$. Berdasarkan pernyataan tersebut, bioaktivitas ekstrak Crella papilata dapat dikategorikan aktif dan mempunyai potensi yang menjanjikan sebagai antitumor. Menurut Faulkner (2000), spons mempunyai 
sejarah evolusi yang panjang sehingga mempunyai kesempatan untuk menyempurnakan pertahanan kimianya. Mekanisme penyempurnaan pertahanan kimia pada spons memang tidak bisa secara langsung disamakan dengan peningkatan potensi aktivitas biomedisnya. Namun demikian, terdapat korelasi yang baik antara keduanya. Hal tersebut dapat dijelaskan dengan fakta bahwa metabolit primer yang dimiliki spons seperti enzim dan reseptor cenderung terawetkan di alam (tidak berevolusi), sementara metabolit sekunder yang berfungsi sebagai pertahanan diri cenderung mengalami perubahan (evolusi) sebagai bagian dari proses adaptasi.

Russel Kerr (2003) dalam Widjhati et al. (2004), mengemukakan skenario kaitan antara spons dengan efek antikanker dan antibiotik yang dimilikinya. Sebagai binatang invertebrata yang tidak dapat berpindah, spons harus mempertahankan diri dari predator maupun persaingan antara mereka sendiri untuk mempertahankan wilayah pertumbuhannya. Spons berkembang biak secara seksual dan aseksual. Cara aseksual dengan membentuk tonjolan tunas (budding). Apabila dua spesies spons dalam pertumbuhannya saling bertemu maka ada kemungkinan untuk melapisi atau dilapisi. Yang dilapisi akan kalah dan mati. Untuk itu mereka bersaing dan berevolusi untuk membuat senjata beracun yang berbentuk metabolit sekunder untuk melawan pertumbuhan sel yang sangat cepat, seperti ciri-ciri pertumbuhan sel kanker.

\section{KESIMPULAN}

Berdasarkan hasil penelitian yang telah dilakukan, dapat diketahui bahwa ekstrak Crella papilata memiliki aktivitas sitotoksik yang tinggi terhadap sel tumor HeLa dan mieloma. Respon bioaktivitas ekstrak Crella papilata terhadap sel HeLa lebih tinggi dibandingkan terhadap sel mieloma. Nilai LC $_{50}$ ekstrak kasar metanol Crella papilata terhadap sel HeLa sebesar 12,06 ppm dan terhadap sel mieloma sebesar 18,91 ppm, sedangkan nilai LC $_{50}$ fraksi metanol Crella papilata terhadap sel HeLa sebesar 7,63 ppm dan terhadap sel mieloma sebesar 17,30 ppm. Metabolit sekunder pada fraksi metanol spons Crella papilata asal Taman Nasional Laut Kepulauan Seribu mempunyai prospek yang menjanjikan untuk diteliti lebih lanjut bioaktivitasnya sebagai antitumor.

\section{DAFTAR PUSTAKA}

Anonymous. 2001. Chemical Dictionaries of Natural Products. Electronic edition. Chapman \& Hall.

Anonymous. 2005. Cell quanti- MTT assay kits. Bioassay system Inc. USA. http : www.i-dna.biz . Accessed October 29, 2005.
Carballo, J.L., Hernadez-Inda, Z.L., Perez, P., and Gravalos, M.D. 2002. A comparison between two brine shrimp assay to detect in vitro cytotoxicity in marine natural product (methodology article). BMC Biotechnology. 2: 1-5.

Faulkner, D.J. 2000. Marine Pharmacology. Antonie van leeuwenhoek. 7: 135-145.

Gudbjarnason, S. 1999. Bioactive Marine Natural Products. Rit fiskideiddal. 16:107-110.

Herefa, F.H. 2000. Pembudidayaan Artemia untuk Pakan Udang dan Ikan. Penerbit PT. Penebar Swadaya. Jakarta. $10 \mathrm{pp}$.

Hughes, D. and Mehmet, H. 2003. Cell Proliferation and Apoptosis. BIOS scientific Publishers Ltd. Oxford. p.18-22.

Maxwell J.R., Ehrlich, H. and Speer, L. 2005. Medicines from the Deep. Paper on Natural Resources Council. Marine Conservation Biology Institute. March 2005.

Meyer, B.N., Ferrigni, N.R., Putman, J.E., Jacobsen, L.B., Nichols, D.E. and Mc Laughlin, J.L. 1982. Brine shrimp: a convenient general bioassay for active plant constituents. Planta Med. 45: 35-34.

Pabel, C.T., Joachim, V., Wilde, C., Franke, P., Hofemeister, J., Adler, B., Bringmann, G., Hacker, J. and Hentschel, V. 2003. Antimicrobial activities and matrix assisted laser desorption/ionization mass spectrometry of Baccilus isolated from the marine spons Aplysina aerophoba. Mar. Biotechnol. p. 424434.

Proksch, P., Ebel, R., Edrada, R.A., Schupp, P., Lin, W.H., Sudarsono, Wray, V. and Steube, K. 2003. Detection of pharmacologically active natural pro-ducts using ecology, selected examples from Indopacific marine invertebrates and spons-derived fungi. Pure Applied Chem. 75: 343-352.

Rachmat, R., Kobayashi, M. dan Rasyid, A. 2001. Substansi antikanker dari spons sp. asal Baranglompo, Kepulauan Spermonde, Indonesia. Prosiding Seminar Laut Nasional III. Jakarta. 23 pp.

Sennett, S.H., Mc Carthy, P.J., Wright, A.E. and Pomponi, S.A. 2002. Natural products from marine invertebrates: The Harbor Branch Oceanographic Institution experience. Pharmaceutical News. 9: 438-488.

Sismindari, A.S., Handayani, Yulia, S. dan Candra, E. 2002. Potent effect of protein extract containing ribosome-inactivating proteins (RIPs) isolated from Erythrina fusca lour on cancer cells. Indon. J. Biotechnol. Dec 2002. p. 559-564.

Sumaryono, W. 2004. Prospek, tantangan dan strategi pengembangan bioteknologi kelautan di Indonesia. Makalah dalam Forum Bioteknologi Kelautan dan Perikanan Indonesia. Pusat Riset Pengolahan Produk dan Sosial Ekonomi Kelautan dan Perikanan. Jakarta, 25 Maret 2004. 14 pp.

Widiastuti, D.K., 2004. Potensi Antikanker Senyawa Bioaktif Ekstrak Kloroform dan Methanol Makroalga Sargassum Duplicatum J. Agardh. Skripsi. Fakultas Biologi. UGM. 28 pp.

Widjhati, R.A., Supriono dan Subiantoro. 2004. Pengembangan senyawa bioaktif dari biota laut 
(review kegiatan penelitian biota laut di BPPT). Makalah dalam Forum Bioteknologi Kelautan dan Perikanan Indonesia. Pusat Riset Pengolahan Produk dan Sosial Ekonomi Kelautan dan Perikanan. Jakarta, 25 Maret 2004. p. 89-95.

Wikanta, T., Suryaningrum, Th.D., Sugiyono, Nursid, M., Munifah, I., Fajarningsih, N.D, Krisnawang, H. dan Januar, H.I. 2005a. Laporan Teknis Riset Ekstraksi Senyawa Bioaktif dari Biota Perairan Tahun 2005. Pusat Riset Pengolahan Produk dan Sosial Ekonomi Kelautan dan Perikanan. Jakarta.
Wikanta, T., Januar, H.I. dan Nursid, M. 2005b. Uji aktivitas antiokasidan, dan sitotoksisitas ekstrak alga merah Rhodymenia palmata. J. Penel. Perik. Indonesia. 2(4).

Williams, D.E. and Andersen, R.J. 2006. Coral Reefs to Clinical Trials : Bio Prospecting for Drugs from the Sea. Presented on International Seminar and Workshop on Marine Biodiversity and their Potential for Developing Bio-pharmaceutical Industry in Indonesia. Jakarta. Mei 2006. 
